Gut, 1987, 28, S1, 117-120

\title{
Effects of calcium mediated secretagogues on the growth of pancreatic acinar cells in vitro
}

\author{
CD LOGSDON
}

From the Cell Biology Research Laboratory, Mount Zion Hospital and Medical Center, San Francisco, CA and the Department of Physiology, University of California, San Francisco, CA, USA

SUMmaRY Caerulein, CCK8, and gastrin, hormones which interact with the cholecystokinin receptor increased the growth of mouse pancreatic acinar cells in vitro. In contrast, bombesin, substance $\mathrm{P}$, and carbachol, factors which interact with separate receptors, and stimulate pancreatic secretion similarly to CCK by mobilising intracellular $\mathrm{Ca}^{2+}$, did not have any effect on the growth of pancreatic acinar cells in vitro. These results suggest both a unique role for cholecystokinin in the physiological regulation of the pancreas and that the mechanisms that mediate the trophic effects of cholecystokinin are different from those that mediate secretion.

Rapid and relatively large increases in pancreatic growth occur under certain circumstances, such as the regenerative response after surgical resection, ${ }^{1}$ and as an adaptive response to certain diets. ${ }^{2}$ Little is known concerning the regulation of pancreatic growth. Trophic effects in vivo have been clearly demonstrated for cholecystokinin and its analogue caerulein..$^{3-7}$ It is not known, however, whether this is a direct effect, whether this trophic activity is shared by other $\mathrm{Ca}^{2+}$ mobilising hormones, nor what intracellular mechanisms are involved. In part this is because of the complexity of the in vivo situation. Pancreatic secretagogues can affect the release of other regulatory factors, and/or have general systemic effects, interactions that complicate the interpretation of experimental data.

\section{Methods}

In vitro models offer advantages for elucidation of direct effects of hormones and their mechanisms of action. We have recently described a primary culture system of adult mouse pancreatic acinar cells grown as monolayers on collagen gels. ${ }^{8,9}$ In order to identify regulatory hormones and to elucidate the mechanisms involved in initiation and control of pancreatic growth, in the current report we have tested the direct effects of several $\mathrm{Ca}^{2+}$-mobilising secretagogues on the growth of pancreatic acinar cells in vitro.

Address for correspondence: Dr Craig D Logsdon, Cell Biology Research Laboratory, PO Box 7921, Mount Zion Hospital and Medical Center, San Francisco, CA 94120 , USA.
PREINCUBATION THYMIDINE INCORPORATION ASSA Y

The rate of DNA synthesis was assayed using a preincubation thymidine incorporation assay that has been previously described. ${ }^{\mathbf{8} 9}$ Cells were plated and allowed to incubate for 24 hours in a basal media to allow for equal attachment. Subsequently, the various factors being tested were included in the culture medium. The preincubation period was two days, after which $0.1 \mu \mathrm{Ci} / \mathrm{ml}\left[{ }^{3} \mathrm{H}\right]$ thymidine was added for an additional 24 hours (total exposure to experimental factors: three days; total time in culture: four days). Subsequently, the cultures were washed with $154 \mathrm{~mm}$ $\mathrm{NaCl}$ and removed from collagen gels by treatment with collagenase $(0.1 \mathrm{mg} / \mathrm{ml})$ for 45 minutes at $37^{\circ} \mathrm{C}$. The cells were then washed with $154 \mathrm{mM} \mathrm{NaCl}$ and sonicated in $1 \mathrm{ml} \mathrm{H}_{2} \mathrm{O}$. To determine the protein content a $100 \mu \mathrm{l}$ aliquot of each cell sonicate was diluted $1: 1$ with $0.2 \mathrm{~N} \mathrm{NaOH}$, boiled for two minutes, and the protein measured with Bio-Rad reagent; BSA diluted in $0.1 \mathrm{n} \mathrm{NaOH}$ was used as a standard. To determine the incorporation of $\left[{ }^{3} \mathrm{H}\right]$ thymidine into DNA, a $0 \cdot 5-\mathrm{ml}$ aliquot of each sonicated sample was precipitated with trichloroacetic acid (TCA; final concn $10 \%$ ) at $4^{\circ} \mathrm{C}$ for 15 minutes. The precipitates were washed twice with cold $10 \%$ TCA and dissolved in $1 \mathrm{ml} 0.1 \mathrm{~N} \mathrm{NaOH}$. Radioactivity in $0.5 \mathrm{ml}$ of this solution was measured by liquid scintillation counting. Incorporation of $\left[{ }^{3} \mathrm{H}\right]$ thymidine was expressed as percentage of total counts per minute per milligram protein. 




Fig. 1. Effects of $C C K 8$, caerulein, gastrin, carbachol, bombesin and substance $P$ on the incorporation of $\left[{ }^{3} H\right]$ thymidine into DNA by cultures of pancreatic acinar cells. Cultures were exposed to agents for 3 days, the final 24 hours of which included $0 \cdot 1 \mu \mathrm{Ci}\left[{ }^{3} \mathrm{H}\right]$ thymidine. Values expressed as a percentage of control incorporation per $\mathrm{mg}$ protein and are means $\pm S E M$ for $6-9$ experiments. Reproduced from ref. 9.

\section{CELL CULTURE}

Pancreatic acini were isolated and cultured as previously described. ${ }^{8,9}$ Basal media consisted of Waymouth's medium containing $100 \mathrm{U} / \mathrm{ml}$ penicillin, $100 \mu \mathrm{g} / \mathrm{ml}$ streptomycin, $50 \mu \mathrm{g} / \mathrm{ml}$ amphotericin B, $0.5 \mathrm{mM}$ IBMX, $0.2 \mathrm{mg} / \mathrm{ml}$ soybean trypsin inhibitor, and $2.5 \%$ fetal bovine serum. To examine their effects on cell DNA synthesis, hormones, growth factors and secretagogues were added to the basal media as indicated. Cultures were maintained in a humidified atmosphere of $5 \% \mathrm{CO}_{2}$ in air at $37^{\circ} \mathrm{C}$ and the media was changed every day.

\section{Results}

EFFECTS OF HORMONES THAT INTERACT WITH THE CCK RECEPTOR

Effects of various hormones on the incorporation of $\left[{ }^{3} \mathrm{H}\right]$ thymidine into DNA of pancreatic acinar cells in culture were examined using a preincubation $\left[{ }^{3} \mathrm{H}\right]$ thymidine incorporation assay. In this assay cells were plated in basal medium containing a low level of fetal bovine serum $(2.5 \%)$ for 24 hours to allow for attachment, then the media were changed to basal plus or minus the hormone to be tested and the cells were cultured for three additional days the last 24 hours of which also included $\left[{ }^{3} \mathrm{H}\right]$ thymidine. Caerulein, CCK8, and gastrin had significant effects on DNA synthesis in the cultures (Fig. 1). Caerulein increased the incorporation of $\left[{ }^{3} \mathrm{H}\right]$ thymidine into cultured pancreatic cells in a dose dependent manner. Cells cultured in the presence of $10 \mathrm{nM}$ caerulein incorporated $285 \pm 19 \% \quad(\mathrm{n}=13)$ of control $\left[{ }^{3} \mathrm{H}\right]$ thymidine. The efficacy and potency of CCK 8 on the induction of $\left[{ }^{3} \mathrm{H}\right]$ thymidine incorporation into DNA in pancreatic acinar cells was similar to that of caerulein (Fig. 1). Gastrin also increased the incorporation of $\left[{ }^{3} \mathrm{H}\right]$ thymidine into DNA by the cells, but relatively high concentrations of this hormone were required to elicit a trophic response (Fig. 1).

To determine whether the CCK-receptor mediated increase in the incorporation of $\left[{ }^{3} \mathrm{H}\right]$ thymidine represented an increase in the number of cells incorporating thymidine we examined the effects of caerulein on the nuclear labelling index of the cultures. In four separate experiments, $10 \mathrm{~nm}$ caerulein increased the percentage 


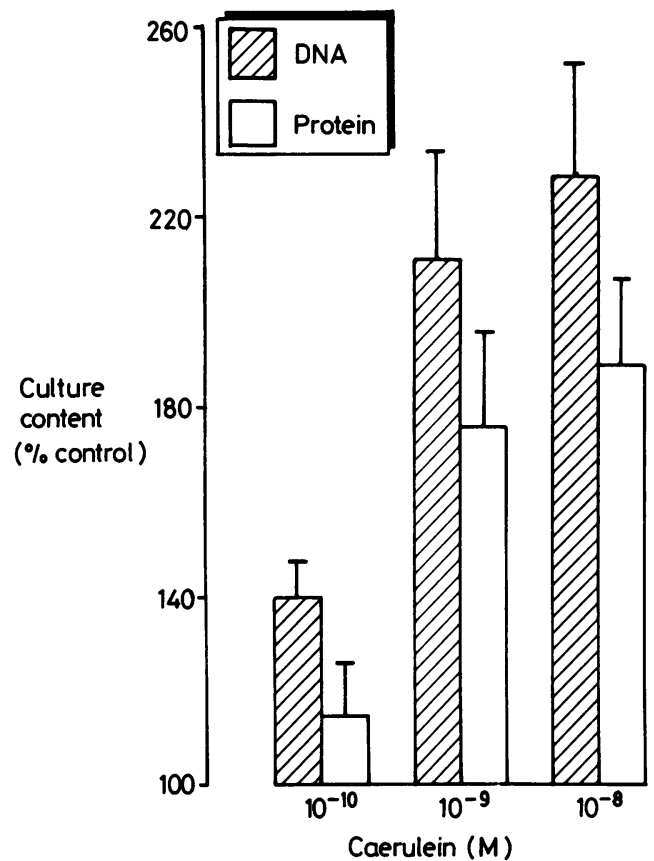

Fig. 2. Effects of caerulein on DNA and protein content of pancreatic monolayer cultures. Cultures were grown for 9 days in the presence of various concentrations of caerulein, then analysed as to contents of DNA (hatched bars) and protein (open bars). Results are expressed as per cent of control and are means $\pm S E$ of the means for 9 experiments in each of which each condition was assayed in triplicate cultures. Reproduced from ref. 8.

of nuclei which incorporated $\left[{ }^{3} \mathrm{H}\right]$ thymidine as judged by autoradiography from $8.4 \pm 2.6 \%$ in control cultures to $26.5 \pm 1.9 \%$. This three fold increase in the number of labelled nuclei is comparable with the three fold increase in $\left[{ }^{3} \mathrm{H}\right]$ thymidine uptake. Caerulein also increased the protein and DNA contents of the cultures in a dose dependent manner (Fig. 2). These results support the hypothesis that activation of the CCK receptor stimulates pancreatic cell division.

\section{EFFECTS OF OTHER $\mathrm{Ca}^{2+}$-MOBILISING}

\section{SECRETAGOGUES}

In contrast with those hormones which interact with the CCK receptor, neither bombesin, substance $P$, nor carbachol were effective at stimulating $\left[{ }^{3} \mathrm{H}\right]$ thymidine incorporation into DNA (Fig. 1). Insufficient concentrations cannot explain the lack of effect of these agents, because they were tested at concentrations which are equivalent, in terms of the ability to stimulate amylase release, to the effective concentrations of CCK8 or caerulein.

During culture the acinar cells undergo significant changes in their physiology.$^{8}$ One possibility, therefore, was that the cells lost responsiveness to carbachol or bombesin during the 24 hour attachment period associated with the standard preincubation thymidine incorporation assay. Therefore, experiments were conducted in which the usual 24 hour attachment period was eliminated and cultures were treated with caerulein, bombesin, or carbachol immediately after isolation. In these experiments, the incorporation of $\left[{ }^{3} \mathrm{H}\right]$ thymidine after treatment with $10 \mathrm{nM}$ caerulein was $281 \pm 66 \%(\mathrm{n}=3)(\mathrm{p}<0.05)$ of control incorporation, while cells treated with $10 \mathrm{~mm}$ bombesin or $1 \mu \mathrm{M}$ carbachol incorporated $111 \pm 14 \%$ or $85 \pm 8 \%$ of control, respectively.

\section{Discussion}

We have evaluated the effects of several pancreatic secretagogues known to mediate their secretory effects via an ability to mobilise intracellular $\mathrm{Ca}^{2+}$, on the growth of pancreatic acinar cells in culture. Only those hormones which interact with the CCK receptor stimulated the growth of the pancreatic acinar cells in vitro. Mouse acinar cells in culture responded trophically to caerulein in terms of increases in protein and DNA, $\left[{ }^{3} \mathrm{H}\right]$ thymidine incorporation into DNA, and nuclear labelling index. CCK8 was found to be equally as effective as caerulein in stimulating the growth of the pancreatic cells. Gastrin, a closely related peptide hormone, also stimulated $\left[{ }^{3} \mathrm{H}\right]$ thymidine incorporation of the cultures. Binding studies have indicated that gastrin interacts with the CCK receptor with an affinity which is at least 1000 fold lower than that of CCK8. ${ }^{10}$ Thus the weak effect of gastrin on the cultures is probably due to its weak ability to interact with the CCK receptors. These results confirm the important role of cholecystokinin as a growth regulator of the pancreas and indicate that its effects are because of a direct interaction with pancreatic acinar cells.

Neither bombesin, substance $P$, nor carbachol, agents which do not interact with the CCK receptor, but whose receptors stimulate similar increases in intracellular $\mathrm{Ca}^{2+}$ and phosphotidylinositide turnover in pancreatic acinar cells, had trophic effects in vitro. In vivo administration of bombesin has been reported to increase pancreatic growth $;^{11}$ however, bombesin is also known to stimulate the release of several other hormones. ${ }^{12}$ Acetylcholine analogues have been reported to increase ${ }^{4,13}$ or to have no effect ${ }^{14}$ on pancreatic weight, and to increase ${ }^{13}$ or have no effect $^{4,14}$ on pancreatic DNA content when administered in vivo. The growth regulatory effects reported for bombesin, and muscarinic cholinergic agonists in vivo were not seen in vitro, suggesting that the in vivo effects may be mediated via indirect interactions.

Cholecystokinin analogues were capable of mediating increases in DNA synthesis, whereas, other secretagogues, with similar modes of action in terms 
of stimulating enzyme secretion, were not capable of stimulating a trophic response. These results suggest, therefore, that increases in intracellular $\mathrm{Ca}^{2+}$ concentration and the turnover of phosphotidylinositides cannot be the sole intracellular mediators of trophic actions of cholecystokinin on pancreatic acinar cells.

I would like to thank Lily Ruslim for her technical assistance, and $\mathrm{Dr}$ J. A. Williams for his helpful discussions. This work was supported by NIH grants AM-32860 and AM-32994, a Cystic Fibrosis Foundation grant and by Mount Zion Hospital and Medical Center.

\section{References}

1 Lehv M, Fitzgerald PJ. Pancreatic acinar cell regeneration. iv. Regeneration after surgical resection. $A m J$ Pathol 1968; 53: 513-35.

2 Melmed RN, El-aaser AA, Holt SJ. Hypertrophy and hyperplasia of the neonatal rat exocrine pancreas induced by orally administered soybean trypsin inhibitor. Biochim Biophys Acta 1976; 421 : 280-8.

3 Dembinski AB, Johnson LR. Stimulation of pancreatic growth by secretin, caerulein, and pentagastrin. Endocrinology 1980; 106: 323-8.

4 Mainz DL, Black O, Webster PD. Hormonal control of pancreatic growth. J Clin Invest 1973; 52: 2300-4.

5 Morisset J. Stimulation of pancreatic growth by secretin and caerulein in suckling rats. Biomed Res 1980: 1: 405-9.
6 Solomon TE, Petersen H, Elashoff J, Grossman MI. Interaction of caerulein and secretin on pancreatic size and composition in rat. Am J Physiol 1978; 235: E714-9.

7 Solomon TE, Vanier M, Morisset J. Cell site and time course of DNA synthesis in pancreas after caerulein and secretin. Am J Physiol 1983; 245: G99-105.

8 Logsdon CD. Stimulation of pancreatic acinar cell growth by cholecystokinin, EGF, and insulin in vitro. Am J Physiol 1986; Gastrointest Liver Physiol; 14: G487-94.

9 Logsdon CD, Williams JA. Pancreatic acinar cells in monolayer culture: direct trophic effects of caerulein in vitro. Am J Physiol 1986; 250: G440-7.

10 Sankaran H, Goldfine ID, Devenney CW, Wong KY, Williams JA. Binding of cholecystokinin to high affinity receptors on isolated rat pancreatic acini. $J$ Biol Chem 1980; 255: 1849-53.

11 Solomon TE, Petersen H, Elashoff J, Grossman MI. Effects of chemical messenger peptides on pancreatic growth in rats. In: Gut peptides. Tokyo: Kodansha, 1979: 213-9.

12 Ghatei MA, Jung RT, Stevenson JC, et al. Bombesin: action on gut hormones and calcium in man. $J$ Clin Endocrinol Metab 1982; 54: 980-5.

13 Morisset J, Jolicoeur L, Caussignac Y, Solomon TE. Trophic effects of chronic bethanechol on pancreas, stomach, and duodenum in rats. Can J Physiol Pharmacol 1981; 60: 871-6.

14 Rothman SS, Wells H. Enhancement of pancreatic enzyme synthesis by pancreozymin. Am J Physiol 1967; 213: 215-8. 